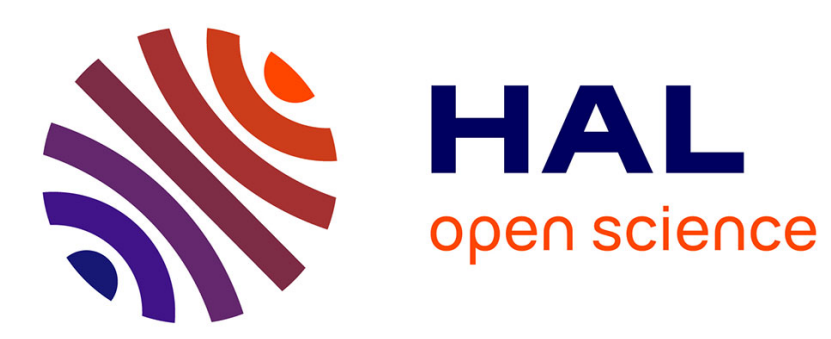

\title{
A glucose electrode using high-stability glucose-oxidase collagen membranes
}

Daniel R. Thevenot, Robert Sternberg, Pierre Coulet

\section{To cite this version:}

Daniel R. Thevenot, Robert Sternberg, Pierre Coulet. A glucose electrode using high-stability glucoseoxidase collagen membranes. Diabetes Care, 1982, 5 (3), pp.203 - 206. 10.2337/diacare.5.3.203 . hal-01083014

\section{HAL Id: hal-01083014 \\ https://hal-enpc.archives-ouvertes.fr/hal-01083014}

Submitted on 14 Nov 2014

HAL is a multi-disciplinary open access archive for the deposit and dissemination of scientific research documents, whether they are published or not. The documents may come from teaching and research institutions in France or abroad, or from public or private research centers.
L'archive ouverte pluridisciplinaire HAL, est destinée au dépôt et à la diffusion de documents scientifiques de niveau recherche, publiés ou non, émanant des établissements d'enseignement et de recherche français ou étrangers, des laboratoires publics ou privés.

\section{(ㄷ)(1)}

Distributed under a Creative Commons Attribution| 4.0 International License 


\title{
A Glucose Electrode Using High-Stability Glucose-Oxidase Collagen Membranes
}

\author{
DANIEL R. THÉVENOT, ROBERT STERNBERG, AND PIERRE COULET
}

A very sensitive glucose electrode was developed using a glucose-oxidase membrane and an anodically polarized platinum disk. Calibration curves were linear over 4.5 concentration decades. It was adapted for human blood samples. The lifetime of glucose-oxidase collagen membranes was greater than 3 yr at $4^{\circ} \mathrm{C}$ and was $\sim 6 \mathrm{mo}$ at $20-30^{\circ} \mathrm{C}$. DiABETES CARE 5: 203-206, MAY-JUNE 1982.

A ong the various techniques available for designing a glucose sensor, the glucose electrode, which combines a glucose-oxidase membrane and an electrochemical detector, is certainly the most developed. Since the first report by Clark et al. ${ }^{1}$ and Updike et al., ${ }^{2}$ different detectors have been tested and different methods of immobilization have been studied. These include entrapment of enzyme solution by semipermeable membrane or by gel, and coreticulation or covalent coupling. ${ }^{3,4}$ However, one of the main problems encountered with such enzyme electrodes has been the instability of enzymatic membranes. We have developed a sensor ${ }^{5-7}$ using glucose oxidase covalently bound to collagen by the acyl-azide procedure ${ }^{8-10}$ which has excellent stability. ${ }^{11}$ This article summarizes the main analytical characteristics of such a sensor, especially with blood samples, and presents the results of stability studies in storage and operating conditions.

\section{MATERIAL AND METHODS}

Glucose electrode. Glucose oxidase was coupled by the previously described acyl-azide procedure applied to insoluble films of highly polymerized reconstituted collagen $^{8-10}$ prepared by the Centre Technique du Cuir (Lyon, France). Carboxyl groups were first esterified by immersion in a methanol-hydrochloride acid solution and then treated by hydrazine before reacting with nitrous acid. The acyl-azide groups of such activated collagen reacted spontaneously with a glucose-oxidase buffered solution.

As pointed out previously, we preferred to use the glucoseoxidase membrane in association with anodic detection of hydrogen peroxide so that the glucose electrode is less dependent on oxygen concentration and so that its output current increases with the glucose level. ${ }^{4}$ Since such detection is not very selective to enzymatically generated hydrogen peroxide, we included in our device a compensating electrode with a nonenzymatic collagen membrane. Except for data processing, material and methods were identical to those previously described..$^{5-7}$

Electrode reponses. When a glucose-containing sample is added to a solution of $0.2 \mathrm{M}$ acetate buffer $\pm 0.1 \mathrm{M} \mathrm{KCI}(\mathrm{pH}$ 5.7 ) into which both electrodes are dipped, three different current-versus-time curves may be recorded:

(1) $I_{2}$ is the output current of the nonenzymatic, compensating electrode, $E_{2} . I_{2}$ is the background response and is usually very low except if the sample contains electrochemical reducing species such as ascorbate, urate, or sulfites.

(2) $\left(I_{1}-k \cdot I_{2}\right)$, where $k$ is close to 1 , and corresponds to the detection of enzymatically generated hydrogen peroxide; it reaches a steady-state value after $2-3 \mathrm{~min}$; this is the steady-state response of the sensor.

(3) $\mathrm{d}\left(\mathrm{I}_{1}-\mathrm{k} \cdot \mathrm{I}_{2}\right) / \mathrm{dt}$ is maximum after $30-50 \mathrm{~s}$; the height of this peak is the dynamic response of the sensor.

Data processing. In order to avoid time-consuming analyses of recordings, we added to the previous equipment a Hewlett-Packard $97 \mathrm{~S}$ programmable table calculator. Its binary coded decimal inputs and outputs were interfaced to the potentiostat and to an electronic buret through a Solea-Tacussel Ionomate 80 digital millivoltmeter (Figure 1). We developed a program that performs two main functions: (1) determination of steady-state response by detecting stable output currents before and after the sample addition, and (2) control of glucose standard additions by the electronic buret. We found that such a device gave printed results and a precision that was equal to graphical analysis of analogue recordings, providing we fixed low enough stability criteria. 


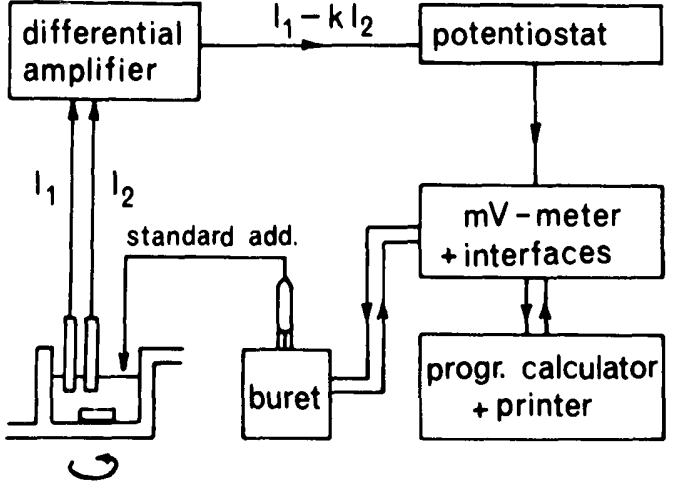

FIG. 1. Block diagram of electrodes and electronics for an automated in vitro glucose electrode.

\section{RESULTS}

Analytical patterns of the glucose electrode. The following analytical patterns were obtained for in vitro glucose determinations: (1) Detection limit reached $10 \mathrm{nM}$ or $10 \mathrm{pmol}$. (2) Glucose concentration was determined when it ranged between $10 \mathrm{nM}$ and $10 \mathrm{mM}$. Steady-state and dynamic responses were proportional to glucose concentration over 4.5 decades, i.e., from $100 \mathrm{nM}$ to $3 \mathrm{mM}$. (3) Response time was 30--50 s and 2-3 min for dynamic and steady-state signals, respectively. Cell and electrode washing time took an additional 2-3 min. (4) Precision, as estimated by standard deviation for 15 assays, reached $2-5 \%$ when glucose concentration ranged between $300 \mathrm{nM}$ and $1 \mathrm{mM}$. (5) When using the differential device, i.e., a compensating electrode, selectivity coefficient was $\sim 5 \times 10^{-4}$ for usual metabolites (fructose, lactose, sucrose) and $\sim 5 \times 10^{-3}$ for electrochemical interferences (hydrogen peroxide, ascorbate, urate). (6) Glucose determinations were performed at temperatures ranging between $15^{\circ} \mathrm{C}$ and $40^{\circ} \mathrm{C}$. Temperature coefficient of responses reached $6-11 \%$ and $4-5 \% /{ }^{\circ} \mathrm{C}$ at $20^{\circ} \mathrm{C}$ and $30^{\circ} \mathrm{C}$, respectively.

Blood glucose determination. The glucose electrode can be used with deproteinized or nondeproteinized samples of whole blood or with serum or plasma. ${ }^{5,7}$ When $50-100 \mu \mathrm{l}$ of these samples was added to the $20-\mathrm{ml}$ buffer solution, the nonenzymatic current $I_{2}$ increased by $5-10 \mathrm{nA}$, whereas $I_{1}$ increased by 15-60 $\mathrm{nA}$, depending on the sample. This result demonstrates the importance of compensating electrochemical interferences and adjusting coefficient $\mathrm{k}$ in $\left(\mathrm{I}_{1}-\right.$ $\mathrm{k} \cdot \mathrm{I}_{2}$ ) determinations by the differential current amplifier. This adjustment was actually tested by checking the balance of the steady-state responses of both electrodes to additions of electrochemical interferences such as hydrogen peroxide.

Figure 2 presents typical glucose assays in samples of nondeproteinized blood plasma. To check possible inhibitory effects on the glucose electrode responses, we usually performed pre- and posttest calibrations with aqueous glucose standards.

Thirty-two different deproteinized whole blood samples were analyzed for glucose. The correlation of the values ob-

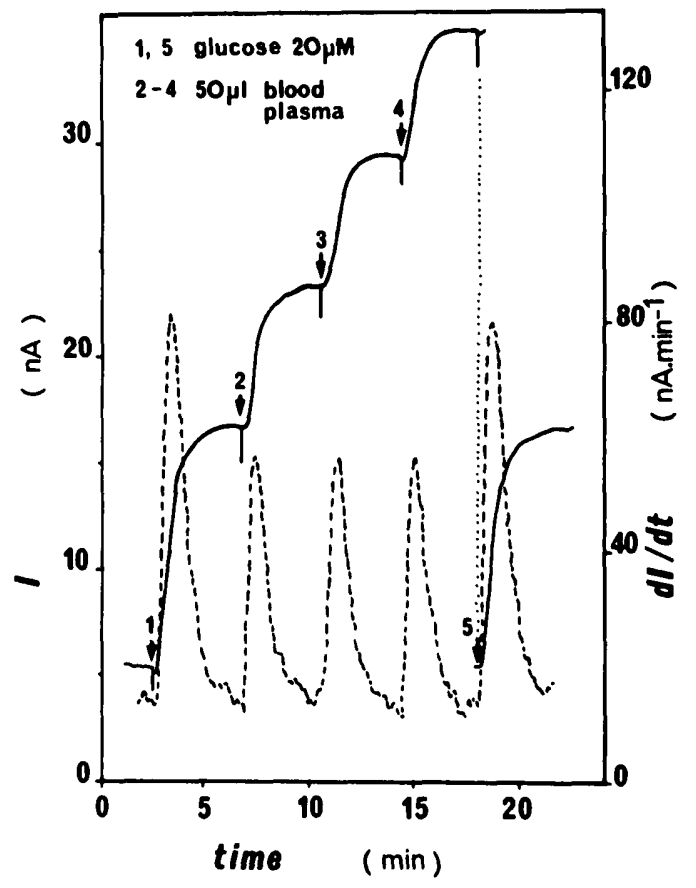

FIG. 2. Glucose determination in blood samples using steady state (-) or dynamic responses(--). Output current I was compensated, i.e., represents $\left(I_{1}-k \cdot I_{2}\right)$.

tained from steady-state and dynamic responses with those of a standard clinical method, i.e., the GOD-Perid Boeringher method, gave $r^{2}$ values of 0.95 and linear regression slopes equal to 1.053 and 0.998 , respectively. ${ }^{7}$

Stability assays of glucose-oxidase collagen membranes. In a previous study, we found that the surface enzyme activities of glucose-oxidase membranes, which ranged from 8 to 80 $\mathrm{mU} / \mathrm{cm}^{2}$ in $0.1 \mathrm{M}$ glucose, gave steady-state responses proportional to these activities. ${ }^{6}$ Thus, the sole calibration of this glucose electrode, i.e., $\Delta \mathrm{I} / \Delta \mathrm{C}$, is a good way to monitor the surface activity of such glucose-oxidase membranes.

Initially, all membranes were stored at $4^{\circ} \mathrm{C}$ before or between tests at $30^{\circ} \mathrm{C}$. Figure 3 shows the evolution of their respective steady-state responses during their operation time at $30^{\circ} \mathrm{C}$. Only two of the seven membranes tested had a significant decrease in response within $20-30 \mathrm{~h}$ operation. We could not correlate the initial values of surface activities to such behavior. In most of the experiments, we used glucoseoxidase membranes giving rise to $\Delta \mathrm{I} / \Delta \mathrm{C}$ values ranging from 2 to $4 \mathrm{~mA} / \mathrm{M}$, i.e., with surface activities ranging from 40 to $80 \mathrm{mU} / \mathrm{cm}^{26}$. These membranes gave stable responses over several months of retesting, accumulating at least 30 -h operation.

In a next step, we decided to store these glucose-oxidase collagen membranes at room temperature on the polarized electrode $E_{1}$ in order to simulate an instrument ready for use. The preparation for a glucose assay consisted only of temperature regulation of the cell at $30^{\circ} \mathrm{C}$. We discovered that such storage conditions do not seem to change the surface activity of the membrane, as shown by the dark circles of Fig- 


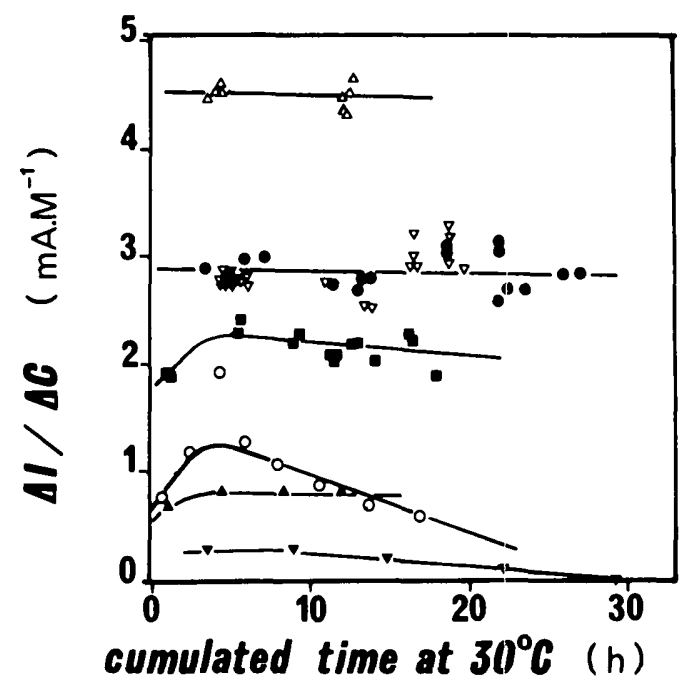

FIG. 3. Stability of steady-state responses during operation with seven different glucose-oxidase collagen membranes. All membranes were tested at $30^{\circ} \mathrm{C}$ and stored at $4^{\circ} \mathrm{C}$, except (O), which was stored at room temperature.

ure 3. Thus we modified our storage procedure so that each freshly coupled membrane was stored at $4^{\circ} \mathrm{C}$ until it was first mounted on an electrode body; then it was kept at room temperature for several months, pressed against a polarized platinum disk, and used for more than 1000 assays at $30^{\circ} \mathrm{C}$, accumulating $1000 \mathrm{~h}$ of operation. The evolution of daily or weekly calibrations for three membranes that had undergone various periods of storage at $4^{\circ} \mathrm{C}$ is presented in Figure 4. Two observations can be made from these results. First, the responses obtained with the same membrane may vary significantly over weeks or months. This does not seem to be re-

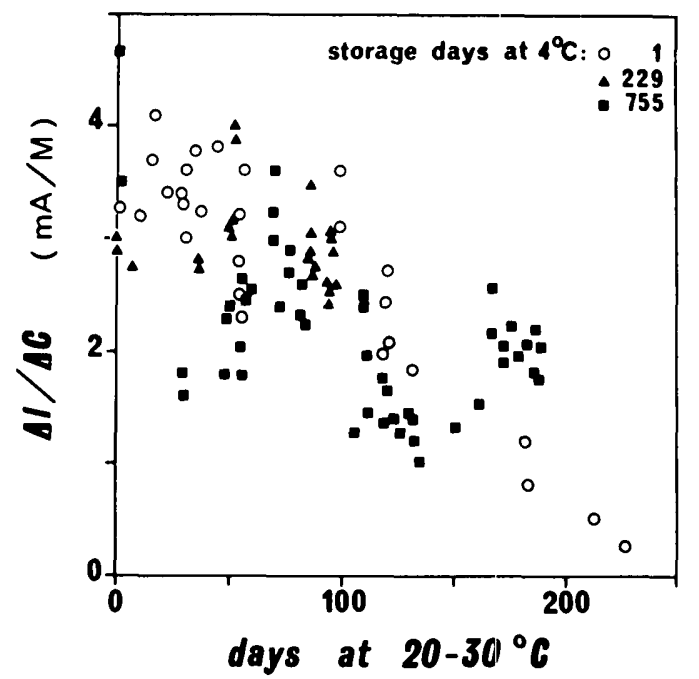

FIG. 4. Stability of steady-state responses when after (O) 1 , (A) 229 , and (1) 755 days at $4^{\circ} \mathrm{C}$. The glucose-oxidase collagen membranes were stored at room temperature and operated at $30^{\circ} \mathrm{C}(\mathbf{\square})$. Data were obtained from ref. 13. lated to poor regulation of the cell temperature, but more probably results from slight variations of geometrical parameters of the electrodes such as platinum disk-membrane distance. Indeed, it was found that an increase of the pressure of this enzymatic membrane against the platinum disk yields an important increase of steady-state responses and an even more important increase in dynamic responses. ${ }^{12}$ Second, the responses do not decrease significantly after more than 2 yr at $4^{\circ} \mathrm{C}$ and 100 or even 200 days at $20-30^{\circ} \mathrm{C}$; for such membranes, the surface activity of which ranged between 40 and $60 \mathrm{mU} / \mathrm{cm}^{2}$, we did not find any correlation between the loss of activity of the enzymatic membranes and their operation time in contact with glucose-containing solutions, such as blood, food, or river water samples. ${ }^{12}$

\section{DISCUSSION AND CONCLUSION}

It is generally claimed that enzyme immobilization, and especially its covalent coupling to an insoluble carrier, stabilizes the enzyme activity. Klibanov ${ }^{14}$ recently reviewed the different factors to which the apparent stability is related.

When the enzymatic load is large enough and thus its intrinsic activity high compared with mass transfer kinetics, the rate-limiting factor is substrate diffusion and the intrinsic activity cannot be observed. Then, the overall reaction rate is minimally affected or not affected at all by a partial deactivation of the immobilized enzyme. ${ }^{15}$ Several illustrations of such behavior have been given by Racine ${ }^{16}$ or Comtat and Mahenc ${ }^{17-19}$ using highly concentrated enzyme solutions entrapped by dialysis film, and by Scheller ${ }^{20}$ or Gondo ${ }^{21}$ using highly concentrated enzyme gels.

By contrast, the glucose-oxidase collagen membranes used in this glucose sensor seem to be kinetically limited by the enzymatic reaction. ${ }^{6.22}$ A partial deactivation of the coupled glucose oxidase would directly affect the overall surface activity of the membrane and the electrode response. The results presented in this report together with those obtained with collagen-bound aspartate aminotransferase ${ }^{11}$ show that even if diffusional effects can partially mask the intrinsic behavior of bound enzymes, the proteinaceous environment provided by collagen seems very favorable for storage and operational stability. Work is in progress to better define some geometric parameters of the glucose electrode, such as the thickness of the liquid film situated between the membrane and the platinum disk, used as a working electrode for hydrogen peroxide detection. Nevertheless, this glucose electrode can be used with daily calibration for several months at a time without replacing its high-stability glucose-oxidase collagen membrane.

From the Laboratoire de Bioélectrochimie et d'Analyse du Milieu, UER de Sciences, Université Paris Val de Marne, Avenue du Général de Gaulle F.94010 Creteil Cédex (DRT, RS), and the Laboratoire de Biologie et Technologie des Membranes du CNRS, Université Claude Bernard (Lyon I), 43, boulevard du 11 novembre 1918 F.69621 Villeurbanne (PC).

Address reprint requests to Daniel R. Thévenot, Laboratoire de Bioélectrochimie et d'Analyse du Milieu, UER de Sciences, Uni- 
versité Paris Val de Marne, Avenue du Général de Gaulle F.94010 Creteil Cédex, France.

\section{REFERENCES}

1 Clark, L. C., Jr., and Lyons, C.: Electrode systems for continuous monitoring in cardiovascular surgery. Ann. N.Y. Acad. Sci. 102: 29-49, 1962.

2 Updike, S. J., and Hicks, G. P.: The enzyme electrode. Nature 214: 986-88, 1967.

${ }^{3}$ Guilhault, G. G.: Enzyme electrode probes. In Immobilized Enzymes, Antigen, Antibodies and Peptides. Weetall, H. H., Ed. New York, Marcel Dekker, 1975, pp. 293-417.

${ }^{4}$ Thévenot, D. R.: Problems in adapting a glucose-oxidase-electrochemical sensor into an implantable glucose sensing device. Diabetes Care 5: 184-89, 1982.

${ }^{5}$ Thévenot, D. R., Coulet, P. R., Sternberg, R., and Gautheron, D. C.: A highly sensitive glucose electrode using glucose oxidase collagen film. Bioelectrochem. Bioenergetics 5: 548-53, 1978.

6 Thévenot, D. R., Sternberg, R., Coulet, P. R., Laurent, J., and Gautheron, D. C.: Enzyme collagen membrane for electrochemical determination of glucose. Anal. Chem. 51: 96-100, 1979.

${ }^{7}$ Sternberg, R., Apoteker, A., and Thévenot, D. R.: Trace glucose electrode for clinical, food and environment determinations. Anal. Chem. Symposia Ser. vol 2. Amsterdam, Elsevier, pp. 46173.

${ }^{8}$ Coulet, P. R., Julliard, J. H., and Gautheron, D. C.: French patent 73-23-283, publ. no. 2, 235, 133, 1973.

${ }^{9}$ Coulet, P. R., Julliard, J. H., and Gautheron, D. C.: A mild method of general use for covalent coupling of enzymes to chemically activated collagen films. Biotechnol. Bioeng. 16: 1055-68, 1974.

${ }^{10}$ Coulet, P. R., and Gautheron, D. C.: Enzyme anchoring on chemically activated collagen membranes. In Analysis and Control of Immobilized Enzyme Systems. Thomas, D., and Kernevez, J. P., Eds. Amsterdam, North Holland, 1976, pp. 165-77.
${ }^{11}$ Coulet, P. R., and Gautheron, D. C.: Resistance to deactivation of enzyme-collagen membranes. Biochimie 62: 543-47, 1980.

12 Sternberg, R.: Enzyme electrodes with enzymes coupled to collagen membrane: determination of glucose and urea. Créteil, Université Paris-Val de Marne, 1979. Thesis.

${ }^{13}$ De Laforcade, V.: Study of an instrument. Application to glucose determination with enzyme electrode. Créteil Université ParisVal de Marne, 1980. Diploma.

${ }^{14}$ Klibanov, A. M.: Enzyme stabilization by immobilization. Anal. Biochem. 93: 1-25, 1979.

15 Thévenot, D., and Sternberg, R.: Rate limiting phenomena in enzyme electrodes. Communication at Journées d'Electrochimie, Strasbourg, 1979.

${ }_{16}$ Racine, P., and Mindt, W.: On the role of substrate diffusion in enzyme electrodes. Experientia (Suppl.) 18: 525-34, 1971.

${ }^{17}$ Durliat, H., Comtat, M., Mahenc, J., and Baudras, A.: Amperometric determination of lactate using enzyme electrode. J. Electroanal. Chem. 66: 73-76, 1975.

18 Durliat, H., Comtat, M., Mahenc, J., and Baudras, A.: Study of the optimal operating conditions of an enzyme electrode specific for lactate. Adaptation for blood titration. Anal. Chim. Acta 85: 31-40, 1976.

${ }^{19}$ Mahenc, J., and Aussaresses, H.: Enzyme electrode specific for glucose using amperometric detection of hexacyanoferrate II. C. R. Acad. Sci. Paris, Ser. C 289: 357-59, 1979.

${ }^{20}$ Scheller, F., and Pfeiffer, D.: Enzyme electrodes. Zeitschrift Chemie 2: 50-57, 1978.

${ }^{21}$ Gondo, S., Morishita, M., and Osaki, T.: Improvement of glucose sensor performance with immobilized glucose oxidase-glucose isomerase system. Biotechnol. Bioeng. 22: 12, 1980.

${ }^{22}$ Coulet, P. R., Sternberg, R., and Thévenot D. R.: Electrochemical study of reactions at interfaces of glucose oxidase collagen membranes. Biochim. Biophys. Acta 612: 317-27, 1980. 